\title{
Speech, Language, Voice and Swallowing Problems of Individuals Who Are 65 and over from Three Different Perspectives: Older Adults, Caregivers and Doctors
}

\author{
Özlem OĞUZ ${ }^{1 *}$ \& Özgenur ÖZZADE** \\ *Üsküdar Üniversitesi, Sağlık Bilimleri Fakültesi, Dil ve Konuşma Terapisi Bölümü İstanbul / Turkey \\ **Üsküdar Üniversitesi, Sağlık Bilimleri Fakültesi, Dil ve Konușma Terapisi Bölümü İstanbul / Turkey \\ ORCID ID: 0000-0001-7590-0028 ORCID ID: 0000-0002-4551-5978
}

\section{ÖZET}

Purpose: The aim of this study is to find out what issues older adults have with language, speech, voice, and swallowing. It is also intended to take opinions on the issues raised above from the doctors, caregivers and the older adults and to compare the opinions of these three different groups. Method: The research included three separate participant groups: older people, doctors, and caregivers. There were 25 individuals in each group, for a total of 75. The data was obtained through face-to-face interviews. Three interview question forms were prepared by the researchers and were used as a data collection tool in the study. Descriptive analysis was conducted. Results: Older participants reported that their speech was satisfactory and that they did not have a hearing impairment that interfered with their communication. It was also found that the participants' voices did not change in comparison to the past, based on what they said. The most common difficulties related to communication attempts, according to caregivers, were hearing problems and memory impairments. The doctors gave the same responses. They also stated that older people were sometimes unable to express themselves effectively, which made the medical evaluation process more difficult for them. Conclusion: The results were consistent with those found in the literature. While the majority of the results relating to doctors' and caregivers' opinions were in line with the literature, there were some discrepancies with perspectives of older people. It demonstrates that three groups should be aware of the issues that may arise during the aging process in order to facilitate early diagnosis and identification, to ensure good contact with others and a successful treatment period.

\section{Üç farklı perspektiften 65 yaş üzeri bireylerin konuşma, dil, ses ve yutma problemleri: Yaşlı bireyler, bakım verenler ve doktorlar}

\section{ABSTRACT}

Amaç: Bu çalışmada yaşlı bireylerin sahip oldukları dil, konuşma, ses ve yutma problemlerinin belirlenmesi amaçlanmaktadır. Ikincil olarak yaşlı bireyler (65+), bakıcılar ve doktorların bu problemlere yönelik yanıtlarının karşılaştırılması hedeflenmektedir. Yöntem: Calışma, 3 farklı katılımcı grubu ile yürütülmüștür. Katılımcı gruplarında yaşlı bireyler, doktorlar ve bakıcılar yer almaktadır. Her grupta 25 katılımcı olmak üzere, çalışmada toplam 75 katılımcı bulunmaktadır. Veriler уӥz yüze görüșmeler aracılı̆̆ıla elde edilmiştir. Veri toplamak amacıyla görüșme sorularını içeren üç form hazırlanmıştır. Veri analizi, betimsel analiz ile gerçekleştirilmiştir. Bulgular: Yaşlı katılımcılar, konuşmalarından memnun olduklarını ve iletişimlerini etkileyen bir işitme problemi yaşamadıklarını belirtmişlerdir. Yaşla birlikte, seslerinin değişmediğini bildirmişlerdir. Bakım verenler ise yaşlı bireyler ile iletişim sürecini etkileyen en yaygın sorunların ișitme ve hafiza bozukluklarından kaynaklı sorunlar olduğunu belirtmişlerdir. Benzer şekilde doktorlar da yaşlı bireyler ile iletişim söz konusu olduğunda, hafıza ve işitme sorunlarının en zorlayıcı sorunlar olduğunu belirtmişlerdir. Ayrıca 65 yaş ve üzeri bireylerin zaman zaman kendilerini etkili bir şekilde ifade edemediklerini ve bu durumun doktorlar için muayene sürecini zorlaştırdığını bildirmişlerdir. Sonuç: Bazı bulgular, alanyazın bulguları ile tutarlılık göstermektedir. 65 yas ve üzeri bireylerin yanıtları ile alanyazın bulguları tutarsızlık göstermektedir ancak bakım verenler ve doktorların yanıtları benzer niteliktedir. Üç grubun da yaşlanma sürecinde yaşanabilecek sorunlar konusunda farkındalığa sahip olmasının, olası bozuklukların erken tespit edilmesi, etkili bir tedavi/rehabilitasyon ve iletişim süreci için önemli olduğu düşünülmektedir.

ARTICLE HISTORY

Received 19 Dec 2020

Accepted 18 Oct 2021

\section{KEYWORDS}

Geriatrics, ageism, communication, language, aged 65 and over individuals

\section{${ }^{1}$ Corresponding author e-mail: ozlem.oguz@uskudar.edu.tr}

Cite: Oğuz, Ö., \& Özzade, Ö. (2021). Speech, language, voice and swallowing problems of individuals who are over 65 from three different perspectives: 65+ individuals, caregivers and doctors. Elderly Issues Research Journal (EIRJ), 14(2), 51-58. doi:10.46414/yasad.847578 


\section{INTRODUCTION}

Aging is a mechanism that has certain distinct characteristics of its own. It is both permanent and unavoidable (Bulduk, 2014). The value placed on quality of life and advancements in medicine have resulted in an increase in lifespan (Aydın, 1999). As advancements in medicine increases, research on the elderly population receives more focus (Folstein, 1994). We now have a better understanding of the psychological, physical, and emotional changes that occur as we age (Bulduk, 2014). These changes have a significant impact on older people's language, speech, communication, voice, and swallowing abilities. Hearing loss/impairments, the most experienced change during aging, directly lead to some problems in speech and language that also can cause some communicational breakdowns. Hearing loss is the third most common chronic condition that can lead to "phonemic regression (Özkan, 1998; Erdoğan, 2016) that can be explained as 'even if words are amplified enough with the appropriate hearing aids and heard, inner ear distortion can cause them to sound garbled and unintelligible (Hear Canada, 2019). According to result findings, the most common complaint among older people with hearing loss is not recognizing the sound, even though they hear it, depending on the degree of the loss (Özkan, 1998). This creates immediate problems for older people when communicating with others. Memory issues caused by cognitive decline are another issue that affects communication and quality of life. It has been noted that older people express a certain level of sadness when they are unable to recall well-known terms (Burke \& Shafto, 2004). As a result of small memory declines, nearly all older people encounter wordfinding difficulties. These kinds of difficulties reduce communication efficiency and attempts, they also contribute to the assumption that older people's language skills are "insufficient" by others (Maviş \& Özbabalık, 2006). It is well recognized that, in addition to the aforementioned challenges, negative communicational, social, economic, and psychological changes, sensory losses, and fear of death may all contribute to depression in the elderly (Eken \& Noyan, 2004). There is a strong connection between depression risk and older people's ability to communicate with others. Hence, it's possible to conclude that communication attempts and success indicate a lower risk of depression.

Changes in speech are often a natural occurrence as a result of physical changes. The movement of the larynx after birth demonstrates that the voice shifts over time (Aronson \& Bless, 2012). The larynx is descending in the throat and this process involves a reduction in muscle tone and respiratory support, atrophy and oedema in the vocal cords, physiological changes due to the aging process, and hormonal changes (Özkan, 1998; Tolga, 2003). These voice variations also have an effect on speech and communication abilities (Aronson \& Bless, 2012). The voice characteristics of older people are hoarse, breathy, and with tremors, according to perceptual research on voice changes (Ryan \& Cabadano, 1978). In their analysis, Ramig and Ringel (1983) found that older people with poor physiological conditions have higher jitter-shimmer values and spectral energy than those with strong physiological conditions and betterpreserved voice characteristics. The study of older professional singers and young people regarding voice characteristics found that they have almost identical values, demonstrating that good physical condition and voice exercises can prevent or at least slow down the deterioration of the voice (Prakup, 2012). Aside from speech-voice changes, the aging process is linked to tooth loss, decreased muscle tone, decreased salivary gland tissue, sensory loss in oral structures, and impairment in oral-motor function (Özkan, 1998; Nazlıel, 1999). Oral-motor dysfunction can also lead to swallowing problems. (Caruso, Mueller \& Shadden, 1995; Santiago, Graça, Rodrigues \& Santos, 2016). Another cause of swallowing problems is the weakening of cartilages and myoelastic structures as people get older. A study of people who had no swallowing problems, dysphagia, or any condition that affects swallowing, drug use, a neurologic disorder, or a surgical history of the head and neck area found that swallowing difficulties occur more often as people age (Santiago et al, 2016). This study also found that, despite having swallowing issues, older people aged 65 and over do not seek treatment in hospitals and are instead diagnosed with swallowing difficulties when being treated for some purpose. Swallowing time is much longer in older people than in younger people, according to reports.

The aim of this research is to discover what problems people over the age of 65 have with speech, language, voice, and swallowing. Furthermore, it is intended to ascertain the views of doctors and caregivers on these issues, as well as to compare the views of these three groups. Clinical recommendations regarding assessment and intervention in the older population are based on others practice, experiences, assumptions. The present study also aims to give clinical considerations in speech and language therapy for older population

\section{MATERIAL AND METHOD}

The study was carried out in three stages as descriptive research. Three separate participant groups were identified, and each group's interview questions were prepared.

\section{Participants}

The elderly aged 65 and up, as well as the very old aged 85 and up, are classified as psychogeriatric senile, according to the World Health Organization (Beğer \& Yavuzer, 2012). Therefore, if a participant was 65 years or older, they were included in the study in order to provide clinical consideration to the senior population.

The research included three separate participant groups: people aged 65 and over, doctors, and caregivers. The inclusion and exclusion criteria were identified before reaching out to the participants. There were 25 people in each participant category. The research was completed by 75 participants who met the inclusion criteria. Before participating in the current study, the subjects gave their informed consent and were informed about the study's intent. 
Thirteen of the individuals from Tekirdağ Zübeyde Hanım Senior Center, and 12 of them lived with their families, were recruited for the participant group including people aged 65 and over. The person in charge of elderly care facility was contacted with, and the study was done with individuals who were interested in the study. Individuals with neurological disabilities and disorders were excluded from the sample based on details given by caregivers. Older people were eligible for the study if they were 65 years old or older and willing to participate in the study.

The second group of participants consisted of caregivers or relatives of people aged 65 and over. Half of the participants (52\%) had a bachelor's degree, and $28 \%$ of the participants had older-carerelated vocational training. Depending on their working hours, caregivers were included as participants. In order to be included in this category, caregivers had to have worked in the same institution as a caregiver for at least 6 months.

Doctors who diagnose, treat, and prevent diseases and disability in older adults were included in the third participant groups. Tekirdağ $(\mathrm{n}=15,60 \%)$; İstanbul $(n=7,28 \%)$; Edirne $(n=1,4 \%)$; Eskişehir $(n=1,4 \%)$; İzmir $(n=1,4 \%)$ were the cities where the doctors were recruited from. The doctors were asked if they had patients above the age of 65 . After that, they were informed about the interview's content. Those who said that they were able to answer the questions properly were included in the study.

\section{Material}

Survey questions were developed based on a literature review in the field. The researchers prepared three forms containing interview question for each participant group (Özkan, 1998; Martin \& Albert, 1999; Maviş \& Özbabalık, 2006; Erdoğan, 2016; Santiago et al., 2016; Alicura Tokgöz, 2019).
All of the questions were custom-made for each participant group, with any required adjustments were made. Demographic information, speechlanguage-voice-communication and swallowing skills of older population, as well as related difficulties and improvements, were all asked about. First group (+65 individuals) answered a total of 33 questions: 16 short answers and 17 multiple-choice questions with 2-3-4 possible options (such as "often, often, rarely, never" or "situational information"). The caregivers were required to respond to a total of 27 questions, 14 short answers and 13 multiple-choice questions with 2-3-4 options. The form, which was developed to collect information from doctors, had 23 questions, 13 short answers, and 10 multiple choice options with 23-4 options. Face-to-face interviews were held, and if questions were not understood, they were clarified. Subjects of the present study have given informed consent before they participated the study and they were informed about the aim of the study.

\section{Data Analysis}

Descriptive and situational analysis methods were used to interpret the data collected from the participants. The researchers assessed the interview results. In order to gather opinions on differences under categories, common themes were decided by consensus. On the themes that were developed, descriptive analysis of the data was performed.

\section{Ethical Considerations}

The study protocol has been approved by the research institute's human research committee (Üsküdar University) (Number: 61351342).

\section{RESULTS}

A total of 75 people took part in the study, divided into three groups. The tables below contain information about the demographics of the participants (Table 1-2).

Table 1. The demographic data of the older people and caregiver participant groups

\begin{tabular}{|c|c|c|c|c|c|}
\hline \multicolumn{3}{|c|}{ 65+ Participants } & \multicolumn{3}{|c|}{ Caregivers } \\
\hline & $\mathrm{n}$ & $\%$ & & $\mathrm{n}$ & $\%$ \\
\hline \multicolumn{3}{|l|}{ Gender } & \multicolumn{3}{|l|}{ Gender } \\
\hline Female & 12 & 48 & Female & 15 & 60 \\
\hline \multirow{2}{*}{\multicolumn{3}{|c|}{$\begin{array}{l}\text { Male } \\
\text { Age [years] }\end{array}$}} & Male & 10 & 40 \\
\hline & & & \multicolumn{3}{|l|}{ Age [years] } \\
\hline 65-72 & 6 & 24 & $21-33$ & 16 & 64 \\
\hline $73-80$ & 11 & 44 & $34-45$ & 7 & 28 \\
\hline $81+$ & 8 & 32 & $46-57$ & 2 & 8 \\
\hline \multicolumn{3}{|l|}{ Education } & \multicolumn{3}{|l|}{ Education } \\
\hline Illiterate & 4 & 16 & Primary School & 2 & 8 \\
\hline Literate & 3 & 12 & Secondary School & 2 & 8 \\
\hline Primary School & 10 & 40 & High School & 8 & 32 \\
\hline Secondary School & 5 & 20 & University & 13 & 52 \\
\hline High School & 1 & 4 & Vocational Training & & \\
\hline Village Institutes & 2 & 8 & Yes & 7 & 28 \\
\hline & & & No & 18 & 72 \\
\hline
\end{tabular}


Table 2. The demographic data of the doctors

\begin{tabular}{|c|c|c|}
\hline & $\mathrm{n}$ & $\%$ \\
\hline \multicolumn{3}{|l|}{ Gender } \\
\hline Female & 11 & 44 \\
\hline Male & 14 & 56 \\
\hline \multicolumn{3}{|l|}{ Age [years] } \\
\hline $26-38$ & 8 & 32 \\
\hline $39-51$ & 15 & 60 \\
\hline $52-65$ & 2 & 8 \\
\hline \multicolumn{3}{|l|}{ Work Place } \\
\hline State Hospital & 7 & 28 \\
\hline Private Hospital & 12 & 48 \\
\hline Private Clinic & 1 & 4 \\
\hline Education & 2 & 8 \\
\hline Research Hospital & & \\
\hline University Hospital & 2 & 8 \\
\hline Family Health & 1 & 4 \\
\hline Center & & \\
\hline \multicolumn{3}{|l|}{ Experience [years] } \\
\hline $2-10$ & 5 & 20 \\
\hline $11-19$ & 9 & 36 \\
\hline $20-28$ & 10 & 40 \\
\hline $29+$ & 1 & 4 \\
\hline \multicolumn{3}{|l|}{ Specialty } \\
\hline ENT & 8 & 32 \\
\hline $\begin{array}{l}\text { (Otolaryngologists: } \\
\text { Ear, Nose, Throat) }\end{array}$ & & \\
\hline Neurology & 9 & 36 \\
\hline Psychiatry & 5 & 20 \\
\hline $\begin{array}{l}\text { General } \\
\text { practitioner }\end{array}$ & 2 & 8 \\
\hline Physiology & 1 & 4 \\
\hline
\end{tabular}

\section{Findings of the Participants who were 65 and over}

When asked if they had experienced the situations, participants who were 65 and over said they were satisfied with their speech (76\%) and speech rates (88\%). 14 of the participants (56\%) said that they were not heard during communication, with 36 percent stating that they had no idea why. More than half of the participants $(64 \%, n=16)$ said they used short, simple sentences to communicate. When asked to describe their speech, however, they used the terms "short"and "brief."Half of the participants aged 65 and over $(56 \%, n=14)$ said they couldn't tell the difference between their previous voice and their current voice. Those who said their voice changed (44\%) believe their new voice has a lower pitch than their previous one. The presence of hearing disorders did not affect the communication process, according to the participants who had hearing impairments $(36 \%, n=9)$. Word-finding difficulties were identified by the participants $(64 \%, n=16)$, especially with regard to names $(65,5 \%, n=19)$.

The older participants also stated that their dental prosthesis had not interfered with their ability to communicate. According to those who have been impacted, the most annoying feature of dental prosthesis is the appearance, as they felt selfconscious when they didn't have their dental prosthesis on when speaking. The older participants with dry mouth $(60 \%, n=15)$ said it was caused by diabetes $(n=9)$, while 6 said they did not have diabetes. Additionally, 7 of the participants reported that seasonal changes caused them to have dry mouth.

The participants who had swallowing problems (52\%, $\mathrm{n}=13$ ) reported that they had difficulty swallowing granular foods such as rice and as a result of their trouble swallowing, they coughed often.

The details related to the findings are given in the table (Table 3).

Table 3. The findings related to language, speech, swallowing and communication features from the perspective of participants who were 65 and over

\begin{tabular}{lcccc} 
& & & Nes & N \\
& n & \% & n & \% \\
\hline Being misunderstood during communication & 14 & 56 & 11 & 44 \\
Using the term "natural" to describe how they talk. & 9 & 36 & 16 & 64 \\
Not finding any differences in current and previous speech & 11 & 40 & 14 & 60 \\
characteristics & & & & \\
Being content with one's own speech & 19 & 76 & 6 & 24 \\
Being content with one's own speech rate & 22 & 88 & 3 & 12 \\
Using short sentences to communicate & 16 & 64 & 9 & 36 \\
Not clearing throat while talking & 10 & 40 & 15 & 60 \\
Not finding any differences in current and previous voice pitch & 14 & 56 & 11 & 44 \\
Low pitch in voice & 9 & 36 & 16 & 64 \\
Presence of hearing problems & 9 & 36 & 16 & 64 \\
Having no communication issues as a result of hearing difficulties. & 4 & 44 & 21 & 56 \\
Absence of word-finding problems & 9 & 36 & 16 & 64 \\
Having trouble recalling the names & 6 & 37.5 & 19 & 65.5 \\
Having dental prosthesis & 16 & 64 & 9 & 36 \\
Thinking that dental prosthesis has no effect on speech & 11 & 69 & 14 & 31 \\
Having dry mouth & 15 & 60 & 10 & 40 \\
Having food or liquid stuck in your throat when swallowing & 13 & 52 & 12 & 48 \\
\hline
\end{tabular}




\section{Findings of the Caregivers}

The caregivers in the study were asked about the difficulties they had in interacting with the older people (65+). Caregivers were the ones who stayed with the older people to look after them (informal caregivers: $n=18 ; \% 72$ ) or the ones who worked at the senior center (formal caregivers: $n=7 ; \% 28$ ). They stated that the most common reaction they received was frustration. When older people were not understood, they became enraged, according to the caregivers. They were questioned about the characteristics of older people's voices and they reported that older individuals' speech was usually quite long particularly when they talked about the past or to someone they liked. According to caregivers who replied short response questions, another characteristic of older speech was its slowness. However, $16 \%$ of the participants thought older speech was fast, while the rest thought it was normal.
The participants also mentioned that older people clear their throats so often. When older people spoke for long periods of time, they became exhausted and developed aphonia, according to the majority of the caregivers. When the questions related to memory were asked, the caregivers said that older people suffer from memory impairments. Senior moments, on the other hand, were never accepted or accepted as a natural situation by older people because of their ages. Hearing impairments were cited by caregivers as the most significant and difficult cause for older people's communication difficulties. According to caregivers, misunderstandings were the major factor in making communication more difficult, in addition to hearing impairments and the older people were unable to properly communicate their messages because they lacked the ability to express themselves. The following table contains the rest of the details (Table 5).

Table 5. The findings related to language, speech, swallowing and communication features of $65+$ individuals from the perspective of caregivers

\begin{tabular}{lcc}
\hline & $\mathbf{n}$ & $\%$ \\
\hline Getting angry in the situation of not being understood & 10 & 40 \\
Talking for a long time & 13 & 52 \\
Talking slowly & 9 & 36 \\
Clearing the throat frequently & 15 & 60 \\
Getting tired during long talks & 18 & 72 \\
Having aphonia after long period of talks & 4 & 16 \\
Having word-finding problems & 18 & 72 \\
Refusing memory losses & 6 & 24 \\
Accepting senior moments as a normal situation & 4 & 16 \\
Having communication problems due to hearing difficulties & 13 & 52 \\
Misunderstandings due to hearing problems & 2 & 8 \\
Having hearing loss & 14 & 56 \\
Not being able to adequately express oneself & 5 & 20 \\
\hline
\end{tabular}

\section{Findings of the Doctors}

When asked whether they were aware of speech and language therapy services, the majority of the doctors (76\%) said they were, while only $24 \%$ said they were not. The ones who knew about the speech and language therapy services were mostly learned about them through their medical schooling. The doctors said they had never referred patients aged 65 and over to a speech and language therapist (40\%). On the other hand, $60 \%$ of the doctors said they were only given referrals once in a while. Patients aged 65 and over visited the doctors mostly for hearing loss and memory impairments, according to the doctors. Other causes for consultation included dizziness and tinnitus, in addition to these impairments. These patients have sought medical help because they had a breathy voice and a dry mouth. The patients who went to the doctors because of communicational problems told the doctors that they couldn't understand what was being said even though they had heard it. Those who struggled with communication also told doctors that they were not so eager to communicate with others. Another reason for consultation was memory problems, especially those relating to events that occurred recently. When the doctor participants were asked about the issues that they encountered during the consultation, they reported that older patients were unable to adequately describe the situations that they were having. Furthermore, due to their hearing impairments, the older patients had difficulty orienting and coordinating themselves in the examination room. In the table, you'll find more information about the results (Table 4). 
Table 4. The findings related to language, voice, swallowing, and communication features of people aged 65 and over from the viewpoint of the doctors

\begin{tabular}{|c|c|c|}
\hline & $\mathbf{n}$ & $\%$ \\
\hline Having breathiness in voice & 9 & 36 \\
\hline Having dry mouth & 12 & 48 \\
\hline Being uneager to start a conversation & 14 & 56 \\
\hline $\begin{array}{l}\text { Not recalling about things and } \\
\text { incidents that occurred recently }\end{array}$ & 8 & 50 \\
\hline $\begin{array}{l}\text { Not understanding what was being } \\
\text { said even though hearing }\end{array}$ & 15 & 60 \\
\hline $\begin{array}{l}\text { Not being able to adequately express } \\
\text { one's dissatisfaction }\end{array}$ & 11 & 44 \\
\hline $\begin{array}{l}\text { Having communication problems due } \\
\text { to hearing problems }\end{array}$ & 8 & 32 \\
\hline $\begin{array}{l}\text { Having orientation and coordination } \\
\text { difficulties }\end{array}$ & 4 & 16 \\
\hline
\end{tabular}

\section{DISCUSSION}

Participants aged 65 and over reported that there was no difference in their voices in the current research. The results about the views of older people differ significantly from those found in related literature. The study conducted by Dehqan (2003) revealed that the vibration of vocal cords was irregular and unstable in the aged population. Also, older people's voices were described as hoarse, breathy, and with tremor during maximum phonation by Ryan and Capadano (1978) and Maslan et al. (2011). Honjo and Isshiki (1980) conducted a study in which the results showed oedema in vocal cords of people who are aged 65-85; \%74 in women, $56 \%$ in men. Men were more likely than women to have vocal cord atrophy, according to the same report ( $76 \%$ vs $26 \%)$. The disparities in results can be explained by the participants' lack of knowledge of voice characteristics. Regrettably, we had to rely on the knowledge provided by the caregivers. As a consequence, it's a little difficult to describe differences. Researchers discovered that variations in muscles and mucous membrane caused by age in men and endocrine changes during menopause in women may be the cause of vocal cord atrophy and males had more pitch variations in their voice than females, according to the research findings (Honjo \& Isshiki, 1980). The older participants in this study indicated that they had differences in their voices, and that these differences were particularly low voice pitch. The data obtained on this issue are compatible with the literature. Smoking and alcohol usage, for example, can modify voice features; however, participants were not asked about these issues. As a result, the change in voice could be due to these habits as well.

According to Erdoğan (2015), hearing loss as a result of aging is the third most common chronic condition. Uhlmann et al. (1989) also stated that hearing impairments are so common in older people and it affects quality of life, cognitive functions, emotional and social situations as well as reducing older people's independence. In this research, caregivers and doctors provided a variety of reasons for hearing difficulties in the older people. Hearing difficulties were also reported by older participants. Although older participants reported that despite their hearing impairment, they were able to communicate well, doctors and carers, on the other hand, indicated the opposite and stated that they had a variety of communication issues when communicating with the older people because of their hearing loss. According to doctors and carers, older people also experience some problems such as not understanding what is being said even though they hear it and they misunderstand what is being said after all. The observations of Ozkan (1998) and Erdoğan (2016) corroborate this conclusion about the importance of communicating challenges as a result of hearing loss is emphasized. These results indicate that the older people are unable to identify communication difficulties. This may be due to the older people's cognitive condition, lack of awareness of communicational breakdowns or the person with whom they interact having insufficient communication skills.

Martin and Albert (1981) claim that the natural aging process causes motor and cognitive abilities to deteriorate. As a consequence, certain perceptual issues such as visual organization disruption and memory impairments arise. Learning and memory difficulties are common after the age of 70, according to $\mathrm{Au}$ and Alpert (1989), and senior moments increase as a result. The cortical and subcortical processes that deal with speech perception and processing undergo another change as people age. As people age, memory, attention and time management skills deteriorate (Martin \& Albert, 1981; Dehqan et al., 2012). These study findings are in line with the findings of the literature. The issues with memory were addressed in the same way by all three groups of participants. Martin and Albert (1981) studied older people's speech and language samples. They have found that older people use more words, more information, a more complex syntactic structure, and more topic comments overall per subject. When compared to the findings of the literature, the results of this study show some inconsistency in the responses of older individuals. The older participants described their speeches as simple and succinct. They also claimed to use short sentences often. Caregivers and doctors' statements, on the other hand, differed significantly from those of participants aged 65 and over. They reported that older people frequently talk about past encounters and people they liked for longer periods of time. It is well understood that as one grows older, one's ability to think critically and consider situations in depth, as well as experience, increases. Older people want to pass on their knowledge and experience to younger people. Perhaps their goal is to guide young people in the right path. As a result, providing additional information and making comments is quite expected. However, it appears that the older people in this study are unaware that they do not use short sentences and that their speech is neither simple nor succinct for those who are around them, such as caregivers and doctors. It's understandable that older individuals might not think about their speech and language 
output enough throughout this guidance in the correct direction.

Caruso et al. (1995) state that sensory loss in oralmotor systems cause older people to have difficulty swallowing. According to Tracy et al. (1989), the timing of swallowing and location differs between younger and older people. Due to variations in oral motor structures and systems, older people's swallowing duration is slower. In the current study, the older participants made similar claims, while doctors and caregivers made no mention of swallowing issues in older people. The explanation for this difference in findings may be that older people believe their swallowing problems are common and natural and do not bring them up with their doctors when they go for medical examination. This assumption is also supported by findings of Santiago et al (2016) that states despite having swallowing issues, older people aged 65 and over do not seek treatment in hospitals. Another explanation may be that during consultation, doctors do not inquire about swallowing abilities of older people.

The older people, the doctors and the caregivers all had different responses to differences in communication, voice, speech, and swallowing in this study. Caregivers and doctors had similar responses to changes in specific areas in the aged population, while older people respond differently.

\section{CONCLUSION}

Because of the small number of participants and the way the study was conducted, the results are limited. However, it will undoubtedly bring insight and inspiration to other researchers and foundations to conduct additional research in order to raise awareness, provide more knowledge, and improve care options for the older population. The findings suggest that older adults are unaware of the changes that occur as part of the natural aging process, while doctors and caregivers are well-versed in and mindful of these changes. Unfortunately, there is still a lack of understanding and awareness. People, particularly those who care for the older people, should be aware of the natural changes that occur as a result of aging and should inform the older people in their lives. Atypical variations may be detected in this way, allowing illnesses or diseases to be diagnosed and treated earlier.

\section{Limitations}

The study's inclusion requirements were not explicitly and thoroughly established at the outset. The older people were chosen based on the opinions of their caregivers. Patients may have been chosen based on the results of a cognitive screening such as 'Mini Mental (MMSE), Montreal Cognitive Assessment (MOCA)' or 'Test your Memory-TR'.

There hasn't been a statistical analysis. This does not rule out the possibility of the collected data revealing information about the current state of the senior population, as other researches have done so. However, the research could be made more accurate and robust by statistical analysis of the data obtained after the variables were determined.
Conflicts of interest

There are no conflicts of interest

\section{REFERENCES}

Alicura Tokgöz, S., Saylam, G., Karaca Umay, E., Keseroğlu, K., Öcal, B., \& Korkmaz, M. H. (2019). Swallowing in elderly individuals: Silent dysphagia risk assessment in the ENT outpatient clinic. Turkish Journal of Geriatrics, 22(3), 353-360.

Aranson A. E., \& Bless, D. M. (2012). Klinik Ses Bozuklukları (Çeviri editörleri: Kılıç, M. A. \& Oğuz, H.) Ankara: Nobel Kitabevi.

$\mathrm{Au}, \mathrm{R}$. , Albert, M. L., \& Obler, L. K. (1989). Language in normal aging: Linguistic and neuropsychological factors. Journal of Neurolinguistics, 4(3-4), 347-364.

Aydın, Z. D. (1999). Yaşlanan dünya ve geriatri eğitimi. Turkish Journal of Geriatrics, 2(4), 79-187.

Beğer, T., \& Yavuzer, H. (2012). Yaşlılık ve yaşlılık epidemiyolojisi. Klinik gelişsim, 25(3), 1-3.

Bulduk, E. Ö. (2014). Yaşlılık ve toplumsal değișim. Turkish Journal of Social Research/Türkiye Sosyal Araştırmalar Dergisi, 18(2), 53-60.

Burke, M. D., \& Shafto, M. A. (2004). Aging and language production. American Psychological Society, 13(1), 21-24.

Caruso, A. J., Mueller, P. B., \& Shadden, B. B. (1995). Effects of aging on speech and voice. Physical \& Occupational Therapy in Geriatrics, 13(1-2), 63-79.

Dehqan, A., Scherer, R. C., Dashti, G., AnsariMoghaddam, A., \& Fanaie, S. (2012). The effects of aging on acoustic parameters of voice. Folia Phoniatrica et Logopaedica, 64(6), 265-270.

Eker, E., \& Noyan, A. (2004). Yașlıda depresyon ve tedavisi. Klinik Psikiyatri, 2, 5-83.

Erdoğan, A .A. (2016). Yaşlılık döneminde işitme kaybı ve işitme kaybına yaklaşımlar. Turkish Journal of Family Medicine and Primary Care, 10(1), 26-33.

Folstein, M. (1994). The noncognitive symptoms of Alzheimer's disease. Journal of the Neurological Sciences, 127(1), 5.

Hearing FAQ. (2019). https://hearcanada.com/ hearing-loss/hearing-faq/ Erișim Tarihi: 10. 05. 2021.

Honjo, I., \& Isshiki, N. (1980). Laryngoscopic and voice characteristics of aged persons. Archives of Otolaryngology, 106(3), 149-150.

Martin, L., \& Albert, M. D. (1999). Changes in language with aging. Seminars in Neurology, 1(1), 4346.

Maslan, J., Leng, X., Rees, C., Blalock, D., \& Butler, S. G. (2011). Maximum phonation time in healthy older adults. Journal of Voice, 25(6), 709-713.

Maviș, İ., \& Özbabalık, D. (2006). Yaşlılıkta nörolojik temelli iletişim sorunları ve dil ve konuşma terapisi. Anadolu Üniversitesi Sosyal Bilimler Dergisi, 6(1), 1-18.

Nazlıel, H. (1999). Yaşlıda ağız ve diş sağlığı. Turkish Journal of Geriatrics, 2(1),14-21. 
Özkan, S. (1998). Yaşlılarda işitme, ses ve konuşma bozuklukları. Turkish Journal of Geriatrics, 1(2), 72-75.

Prakup, B. (2012). Acoustic measures of the voices of older singers and nonsingers. Journal of Voice, 26(3), 341-350.

Ramig, L. A., \& Ringel, R. L. (1983). Effects of physiological aging on selected acoustic characteristics of voice. Journal of Speech, Language, and Hearing Research, 26, 22-30.

Ryan, W., \& Capadano, H.L. (1978). Age perception and evaluative reactions toward adult speakers. Journal of Gerontology, 33, 98-102.
Santiago, L. M., Graça, C. M. D. L., Rodrigues, M. C. D. O., \& Santos, G. B. D. (2016). Characterization of the elderly health in a speech and language therapy perspective. Revista CEFAC, 18(5), 1088-1096.

Tolga, K. (2003). Bir vaka dolayısıyla presbilarinks yaşlılık dönemi disfonisinin sik görülen benign bir sebebi. Turkish Journal of Geriatrics, 6(2), 68-71.

Uhlmann, R. F., Larson, E. B., Rees, T. S., Koepsell, T. D., \& Duckert, L. G. (1989). Relationship of hearing impairment to dementia and cognitive dysfunction in older adults. JAMA, 261(13), 1916-1919. 